\title{
$\mathrm{RF}$ 파워 변화에 따른 ITZO (In-Sn-Zn-O) 박막의 전기적, 광학적, 구조적 특성
}

\author{
서진우 · 정양희 · 강성준

\section{Effect of RF power on the Electrical, Optical, and Structural Properties of ITZO (In-Sn-Zn-O) Thin Films}

\author{
Jin-Woo Seo • Yang-Hee Joung • Seong-Jun Kang ${ }^{*}$ \\ Department of Electrical \& Semiconductor Engineering, Chonnam National University, Yeosu 550-749, Korea
}

\section{요 약}

본 연구에서는 고주파 마그네트론 스퍼터링 법으로 상온에서 RF 파워를 30 에서 $60 \mathrm{~W}$ 로 변화시켜가며 유리기 판 위에 ITZO 박막을 제작하여 전기적, 광학적, 구조적 특성을 조사하였다. RF 파워 $50 \mathrm{~W}$ 에서 증착한 ITZO 박막이 $10.52 \times 10^{-3} \Omega^{-1}$ 의 제일 큰 재료평가지수를 나타내었으며, 이때 $3.08 \times 10^{-4} \Omega-\mathrm{cm}$ 의 비저항과 $11.41 \Omega / s q$. 의 면저항 으로 가장 우수한 전기적 특성을 보였다. 광학적 특성을 측정한 결과, 가시광 영역 (400 800 nm) 에서의 평균 투과 도는 모든 ITZO 박막에서 $80 \%$ 이상으로 나타났다. XRD 측정을 통해 RF 파워에 상관없이 모든 ITZO 박막이 비정 질 구조를 가지고 있음을 확인할 수 있었다. FESEM 과 AFM 으로 ITZO 박막의 표면 형상을 관찰한 결과, 모든 ITZO 박막이 핀홀이나 크랙 같은 결함이 없는 매우 부드러운 표면을 가지며, RF 파워 $50 \mathrm{~W}$ 에서 증착한 박막이 $0.254 \mathrm{~nm}$ 의 가장 작은 표면 거칠기를 나타내었다. 본 연구를 통해 비정질 ITZO 박막이 유기발광다이오드와 같은 차세대 디스 플레이 소자에서 ITO 박막을 대체할 매우 유망한 재료라는 것을 알 수 있었다.

\section{ABSTRACT}

In this study, we fabricated ITZO thin films on glass substrates with various RF power from 30 to $60 \mathrm{~W}$ and investigated the electrical, optical and structural properties. ITZO thin film deposited at 50W exhibited the largest figure of merit $\left(10.52 \times 10^{-3} \Omega^{-1}\right)$ and then its resistivity and sheet resistance were $3.08 \times 10^{-4} \Omega$-cm and $11.41 \Omega /$ sq., respectively. As results of optical characterization, average transmittance of all ITZO thin films were over $80 \%$. ITZO thin films had amorphous structure regardless of the RF power. The FESEM and AFM results showed that all ITZO thin films have a very smooth surface having no cracks and defects and the film deposited at 50W exhibit the smallest surface roughness of $0.254 \mathrm{~nm}$. We found that a amorphous ITZO thin film is a very promising material for replacing ITO in the next display device such as OLED.

키워드 : ITZO 박막, 고주파 마그네트론 스퍼터링, 투과도, 비저항, 재료평가지수

Key word : ITZO thin film, RF magnetron sputtering, Transmittance, Resistivity, Figure of merit

접수일자 : 2013. 11. 27 심사완료일자 : 2014. 01. 17 게재확정일자 : 2014. 01. 29

* Corresponding Author Seong-Jun Kang(E-mail:ferroksj@chonnam.ac.kr, Tel:+82-42-520-5123)

Department of Electrical \& Semiconductor Engineering, Chonnam National University, Yeosu 550-749, Korea

(c) This is an Open Access article distributed under the terms of the Creative Commons Attribution Non-Commercial License(http://creativecommons.org/li-censes/ by-nc/3.0/) which permits unrestricted non-commercial use, distribution, and reproduction in any medium, provided the original work is properly cited. Copyright (C) The Korea Institute of Information and Communication Engineering. 


\section{I. 서 론}

유기발광다이오드 (Organic Light Emitting Diode) 는 고 명암대비, 빠른 응답속도, 낮은 전력소모, 넓은 시 야각, 저가격화 등의 장점을 가지고 있어 차세대 평판 디스플레이 소자로 큰 주목을 받고 있다[1-2]. 고성능의 유기발광다이오드를 개발하기 위해서는 우수한 전도성 과 가시광 영역에서의 높은 투과도를 갖는 정공 주입층 의 역할을 하는 투명 전도막 개발이 필수적이다. 현재 까지는 ITO (In-Sn-O) 박막이 낮은 비저항과 가시광 영 역에서의 높은 투과율 등 우수한 전기적 및 광학적 특 성을 가지고 있어, 유기발광다이오드의 투명 전도막으 로 광범위하게 시용되어 왔다[3-4]. 하지만 ITO 박막은 낮은 일함수, 높은 증착온도와 거친 표면 등의 문제점 을 가지고 있어 유기발광다이오드에 적용하기에 다소 어려운 점이 있어왔다[5-6].

최근에 IZO (In-Zn-O) 나 ITZO (In-Sn-Zn-O) 박막이 유기발광다이오드에서 ITO를 대체할 후보로 관심을 끌 고 있다. ITO에 $\mathrm{ZnO}$ 를 첨가하면 $\mathrm{In}_{2} \mathrm{O}_{3}$ 구조내에 $\mathrm{SnO}_{2}$ 와 $\mathrm{ZnO}$ 의 불혼화성 (immiscibility) 때문에 결정화가 방 해를 받아 ITZO 박막이 안정한 비정질 구조를 갖게 된 다[7]. 이 비정질 구조의 ITZO 박막은 저온에서 증착이 가능하고 이에 따라 매끈한 표면을 가지며, 전기적 및 광학적 특성도 ITO 박막과 유사하거나 더 우수하여 유 기발광다이오드 디스플레이 소자에 응용될 수 있는 가 장 주목받는 재료로 생각되고 있다[8-9]. 그러나, ITZO 박막의 증착 방법과 공정 조건에 따른 구조적 특성과 전기적 및 광학적 특성에 대한 연구는 상당히 미흡하여 유기발광다이오드 적용에 큰 장애가 되고 있다.

본 연구에서는 ITZO 박막을 고주파 마그네트론 스 퍼터링 법으로 상온에서 유리기판위에 증착하여, $\mathrm{RF}$ 파워에 따른 ITZO 박막의 전기적, 광학적, 구조적 특성 을 조사하여 차세대 평판 디스플레이로 주목받고 있는 유기발광다이오드의 투명 전도막으로의 응용 가능성을 조사하였다.

\section{ㅍ. 실험방법}

고주파 마그네트론 스퍼터링 법을 이용하여 유리기 판위에 ITZO 박막을 증착시켰다. 유리기판 표면에 있
는 불순물을 제거하기 위하여 아세톤 (15분) / 알코올 (15분) / 증류수 1 차 (10분) / 증류수 2차 (10분) 초음파 세척을 하였고 질소 가스를 이용하여 건조하였다. ITZO $\left(\mathrm{In}_{2} \mathrm{O}_{3}: \mathrm{SnO}_{2}: \mathrm{ZnO}=90 \mathrm{wt} . \%: 5 \mathrm{wt} . \%: 5 \mathrm{wt} . \%\right)$ 타켓과 유리기판을 스퍼터 챔버내에 고정시킨 후, 초기 진공을 $2 \times 10^{-6}$ Torr 으로 만들었다. 상온에서 공정압력을 3 $\mathrm{mTorr}$ 로 고정시키고, RF 파워를 30 에서 $60 \mathrm{~W}$ 로 변화 시켜가며 ITZO 박막을 제작하였다.

ITZO 박막의 구조적 특성을 조사하기 위해 X 선 회 절기 (XRD, Plilips, PW3020) 를 이용하였으며, 박막의 미세구조와 표면형상은 주사형 전자 현미경 (FESEM, Hitachi, S-4200)과 원자력 현미경 (AFM, SII Nano Technology, SPA400)을 사용하여 측정하였다. X 선 광 전자 분광법 (XPS, VG, ESCALAB 220) 을 이용하여 $\mathrm{ITZO}$ 박막의 구성 성분을 조사하였다. 광학적 특성은 분광 광도계 (UV-Vis Spectrometer, Varian, Cary-500) 를 사용하여 측정하였고, 전기적 특성은 Van der Pauw 법을 이용한 Hall 효과 측정 (Accent, HL5500PC) 을 실 시하여 조사하였다.

\section{III. 결과 및 논의}

그림 1에 상온에서 공정압력을 $3 \mathrm{mTorr}$ 로 고정시키 고, RF 파워를 변화시켜가며 증착한 ITZO 박막의 비저 항과 면저항을 나타내었다. 그림 1 에서 보듯이, $\mathrm{RF}$ 파 워가 30 에서 $50 \mathrm{~W}$ 로 증가함에 따라 비저항은 현저하 게 감소하는 추세를 보였으며, $50 \mathrm{~W}$ 에서 비저항과 면 저항은 각각 $3.08 \times 10^{-4} \Omega-\mathrm{cm}$ 과 $11.41 \Omega / \mathrm{sq}$. 로 가장 작 은 값을 나타내었다. 이와 같이 RF 파워가 증가함에 따 라 비저항과 면저항이 감소하는 원인은 ITZO 박막의 밀도와 밀접한 연관성을 가지고 있다. RF 파워가 증가 하면 투명 전도막의 밀도가 커지고 포논 산란과 이온화 된 불순물 산란이 감소하여 박막의 전기적 특성이 향상 된다는 보고가 있다[10]. 그러나 RF 파워가 $60 \mathrm{~W}$ 로 증 가하면 비저항과 면저항이 다시 감소하는데, 이는 ITZO 박막의 화학양론적 변화에 기인한 것이라고 생각 된다.

그림 2 는 상온에서 공정압력을 $3 \mathrm{mTorr}$ 로 고정시키 고 RF 파워를 변화시켜가며 증착한 ITZO 박막의 투과 도 곡선을 나타낸 것이다. RF 파워에 따른 ITZO 박막의 
두께 차이 때문에 상이한 형태의 투과도 곡선이 측정되 었으며, 이는 박막 두께에 의한 간섭 현상에 의한 것으 로 알려져 있다. RF 파워가 증가함에 따라 가시광 영역 $(400 \sim 800 \mathrm{~nm})$ 에서의 평균 투과도는 84 에서 $80 \%$ 로 감소하는 추세를 나타내었다.

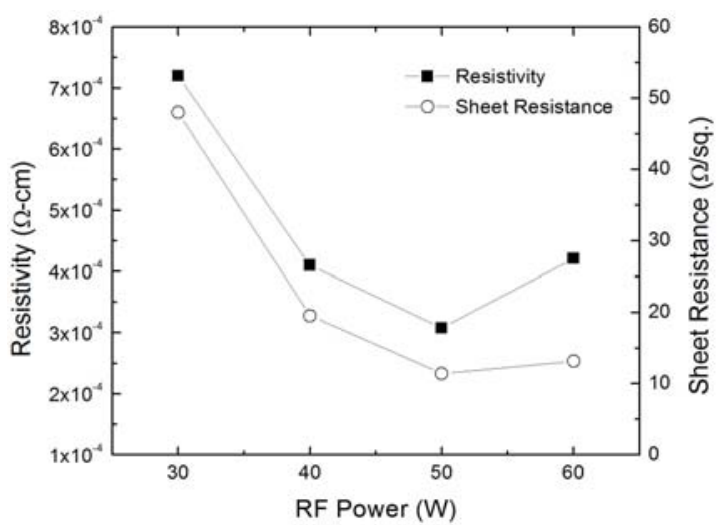

그림 1. RF 파워에 따른 ITZO 박막의 비저항과 면저항 Fig. 1 Resistivity and sheet resistance of the ITZO thin films with various RF power

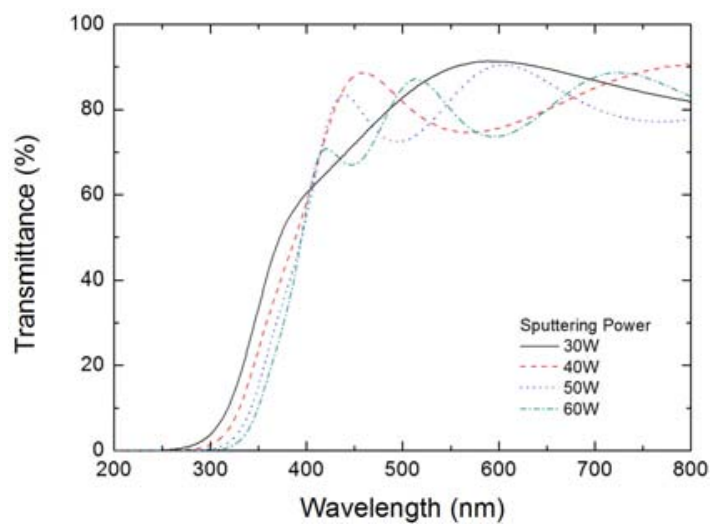

그림 2. RF 파워에 따른 ITZO 박막의 투과도 곡선

Fig. 2 Optical transmission spectra of the ITZO thin films with various RF power

그림 3에 RF 파워에 따른 ITZO 박막의 가시광 영역 에서 평균 투과도와 재료평가지수를 나타내었다. 재료 평가지수는 투명 전도막의 성능을 비교하는 매우 유용 한 도구이다. 면저항과 가시광 영역에서의 평균 투과도 를 이용하여 Haacke에 의해 제안된 식 (1) 의 재료평가 지수를 구할 수 있다[11].

$$
\phi_{T C}=T^{10} / R_{s h}
$$

여기서, $\mathrm{T}$ 는 가시광 영역에서의 평균 투과도이고 $\mathrm{R}_{\mathrm{sh}}$ 는 ITZO 박막의 면저항 이다.

$\mathrm{RF}$ 파워 $50 \mathrm{~W}$ 에서 증착한 ITZO 박막의 가시광 영 역에서의 평균 투과도는 $81 \%$ 로 30 이나 $40 \mathrm{~W}$ 에서 증 착한 ITZO 박막에 비해 약간 떨어지나, 그림 1 에 나타 낸 바와 같이 면저항이 가장 작아 재료평가지수는 $10.52 \times 10^{-3} \Omega^{-1}$ 로 가장 큰 값을 나타내었다. 이를 토대 로 ITZO 박막의 최적의 RF 파워는 $50 \mathrm{~W}$ 임을 알 수 있 었다.

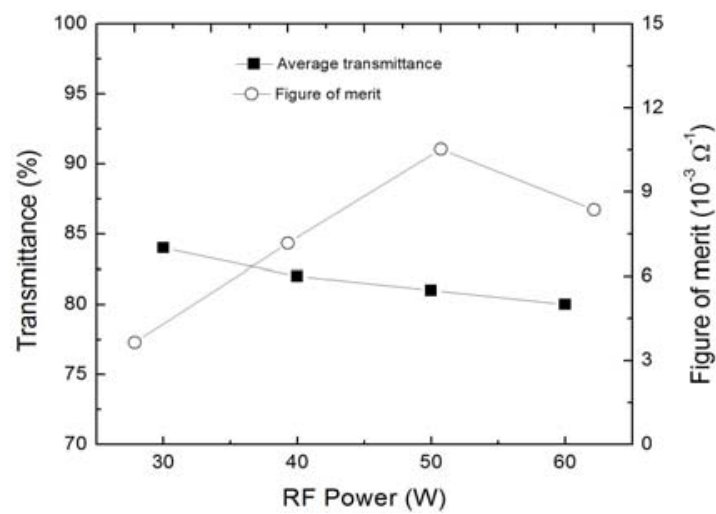

그림 3. RF 파워에 따른 ITZO 박막의 가시광 영역에서의 평균 투과도와 재료평가지수

Fig. 3 Average transmittance in the visible region and figure of merit of ITZO thin films with various RF power

그림 4 는 상온에서 공정압력을 $3 \mathrm{mTorr}$ 로 고정하고 $\mathrm{RF}$ 파워를 $30,40,50,60 \mathrm{~W}$ 로 변화시켜 가며 증착한 $\mathrm{ITZO}$ 박막의 XRD 패턴을 나타낸 것이다. 모든 ITZO 박막은 RF 파워에 상관없이 $2 \Theta$ 값 $33^{\circ}$ 부근에서 완만한 피크를 나타냄을 볼 수 있는데, 이는 ITZO 박막이 비정 질 구조를 가짐을 의미하는 것이다. ITZO 박막이 비정 질 구조를 갖는 이유는 ITO 에 $\mathrm{ZnO}$ 가 첨가됨에 따라 서로 다른 구조를 가지는 물질이 서로의 결정화를 방해 하기 때문인 것으로 판단된다.

특히 $\mathrm{ZnO}$ 가 $\mathrm{In}_{2} \mathrm{O}_{3}$ 에 비해 상대적으로 강한 결합 에 너지를 가지고 있기 때문에 소량의 $\mathrm{ZnO}$ 로도 박막의 결정화를 효과적으로 방해할 수 있었던 것으로 생각된 다[12]. 따라서 비정질 구조의 ITZO 박막은 구조적으 로 안정하며, 이는 유기발광다이오드와 같은 플렉시블 
디스플레이에 적용할 때 매우 큰 장점으로 작용할 수 있다.

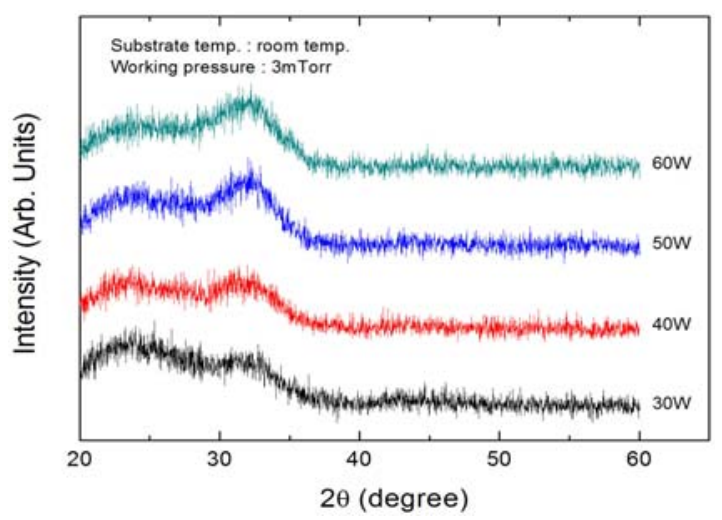

그림 4. RF 파워에 따른 ITZO 박막의 XRD 패턴

Fig. 4 XRD patterns of ITZO thin films with various RF power

그림 5 는 상온에서 공정압력을 $3 \mathrm{mTorr}$ 로 고정시키 고, $\mathrm{RF}$ 파워를 30 에서 $60 \mathrm{~W}$ 로 변화시켜가며 증착한 ITZO 박막의 표면을 FESEM 으로 관찰한 결과를 나타 낸 것이다. 그림 5 에서 보듯이, 모든 ITZO 박막은 핀홀 이나 크랙 같은 결함이 없는 표면을 나타내었다.
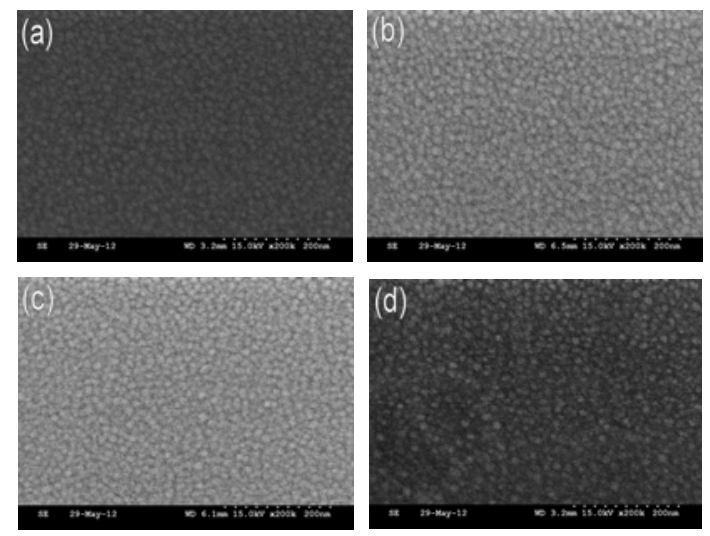

그림 5. RF 파워에 따른 ITZO 박막의 FESEM 표면 사진 : (a) $30 \mathrm{~W}$, (b) $40 \mathrm{~W}$, (c) $50 \mathrm{~W}$, (d) $60 \mathrm{~W}$

Fig. 5 FESEM surface images of the ITZO thin films deposited at (a) $30 \mathrm{~W}$, (b) $40 \mathrm{~W}$, (c) $50 \mathrm{~W}$, (d) $60 \mathrm{~W}$

그림 6 은 $\mathrm{AFM}$ 으로 관찰한 ITZO 박막의 3차원 표 면형상을 나타낸 것이다. RF 파워에 따른 ITZO 박막의
표면 거칠기는 0.254 에서 $0.361 \mathrm{~nm}$ 범위로 조사되었 고, $\mathrm{RF}$ 파워 $50 \mathrm{~W}$ 에서 증착한 박막이 $0.254 \mathrm{~nm}$ 로 가 장 작은 값을 나타내었다. 이는 일반적인 다결정 ITO 박막에 비해서는 상당히 낮은 값이며, ITZO 박막의 낮 은 증착온도와 안정한 비정질 구조 때문이다. 고성능의 유기발광다이오드 디스플레이에서 누설전류와 전류밀 도는 양극으로 사용되는 투명 전도막의 표면 거칠기에 큰 영향을 받기 때문에, ITZO 박막의 낮은 표면 거칠기 는 대단히 중요한 장점이다[13].
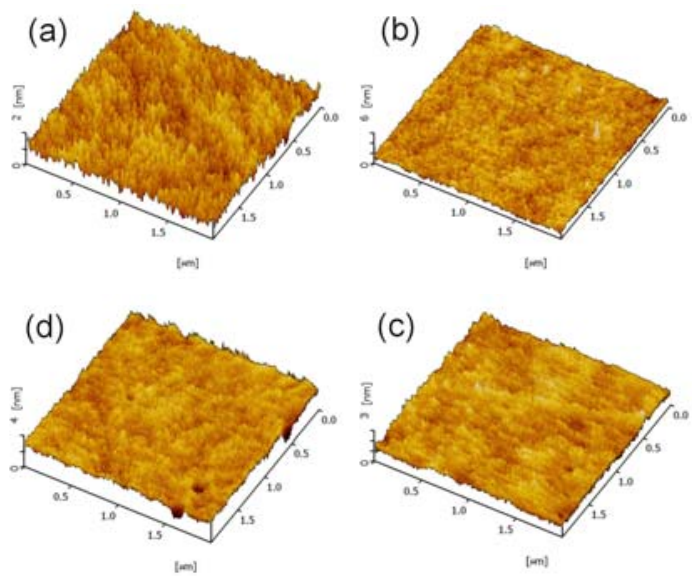

그림 6. RF 파워에 따른 ITZO 박막의 AFM 표면 사진 : (a) $30 \mathrm{~W}$, (b) $40 \mathrm{~W}$, (c) $50 \mathrm{~W}$, (d) $60 \mathrm{~W}$

Fig. 6 AFM surface images of the ITZO thin films deposited at (a) $30 \mathrm{~W}$, (b) $40 \mathrm{~W}$, (c) $50 \mathrm{~W}$, (d) $60 \mathrm{~W}$

그림 7은 $\mathrm{RF}$ 파워 $50 \mathrm{~W}$, 공정압력 $3 \mathrm{mTorr}$ 에서 증 착한 ITZO 박막의 XPS 분석 결과를 나타낸 것이다. 그 림 7 (a) 에서 보듯이, XPS 와이드 스캔 결과에서는 $530.8 \mathrm{eV}$ 에서의 O 1s, $445.1 \mathrm{eV}$ 에서의 In 3d, $487.1 \mathrm{eV}$ 에서의 Sn 3d, $1022.8 \mathrm{eV}$ 에서의 Zn 2p 핵심 준위들을 확인할 수 있었다. O 1s 와 In 3d 피크 강도에 비해 Sn $3 \mathrm{~d}$ 와 $\mathrm{Zn} \mathrm{2p}$ 피크 강도가 상대적으로 약하게 나타나는 데, 이는 본 연구에서 사용한 스퍼터링 타겟의 경우 In (90 wt.\%) 에 비해 Zn (5 wt.\%) 와 Sn (5 wt.\%) 이 낮게 도핑되어 있기 때문인 것으로 생각된다. ITZO 박막의 결합 에너지를 상세히 분석하기 위해 O $1 \mathrm{~s}, \mathrm{In} 3 \mathrm{~d}, \mathrm{Sn}$ $3 d, \mathrm{Zn} 2 \mathrm{p}$ 핵심 준위 스펙트럼들을 그림 7 (b) 에 나타내 었다. 이 스펙트럼들은 In $3 \mathrm{~d}_{5 / 2}, I n_{3 d_{3 / 2}}, \mathrm{Zn} 2 \mathrm{p}_{3 / 2}, \mathrm{Zn}$ $2 \mathrm{p}_{1 / 2}, \mathrm{Sn} 3 \mathrm{~d}_{5 / 2}, \mathrm{Sn} 3 \mathrm{~d}_{3 / 2}$ 각각의 결합 에너지들을 나타내 
는 피크들이다.

이는 K. H. Choi 등[14]이 보고한 ITZO 박막의 XPS 결과와 잘 일치하는 것이다. Phillips 등[15]이 $\mathrm{Zn}(\mathrm{In}$, $\mathrm{Sn})_{2} \mathrm{O}_{4}$ 나 $\mathrm{Zn}_{3}(\mathrm{In}, \mathrm{Sn})_{5} \mathrm{O}_{10.5}$ 등과 같은 스피넬 (spinel) 구조를 갖는 화학양론적으로 근접한 ITZO 박막에서 높 은 전기전도도를 나타낸다고 보고하였지만, 본 연구에 서는 그림 1 에 나타낸바와 같이 Zn 과 $\mathrm{Sn}$ 이 낮게 도핑 된 ITZO 박막에서도 높은 전기전도도 특성을 얻을 수 있었다. 이는 ITZO 박막에서 전기전도도 특성을 결정 짓는 것이 안정한 산소 공공들이기 때문이다. ITZO 박 막의 O 1s 피크는 530.6 과 $532.6 \mathrm{eV}$ 의 2 가지 결합 에 너지로 구성되어 있다. $530.6 \mathrm{eV}$ 의 낮은 결합 에너지 피크는 ITZO 박막에서 In-O 의 결합을 나타내는 것으 로 산소 공공과 관련이 있다. $532.6 \mathrm{eV}$ 의 높은 결합 에 너지 피크는 O-C 결합들의 겹침과 연관되어 있는 것으 로 ITZO 나 ITO 박막에서 많이 보고되고 있다[14, 16-17].

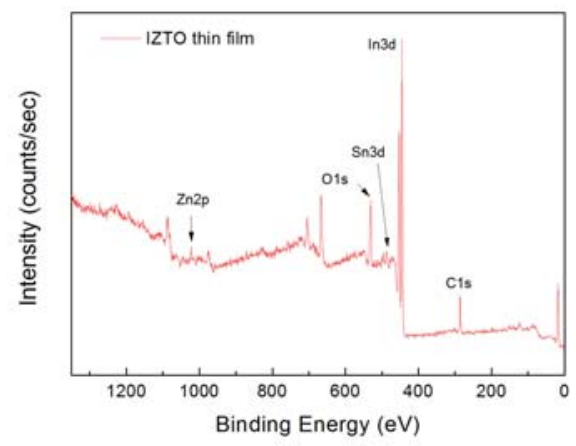

(a)

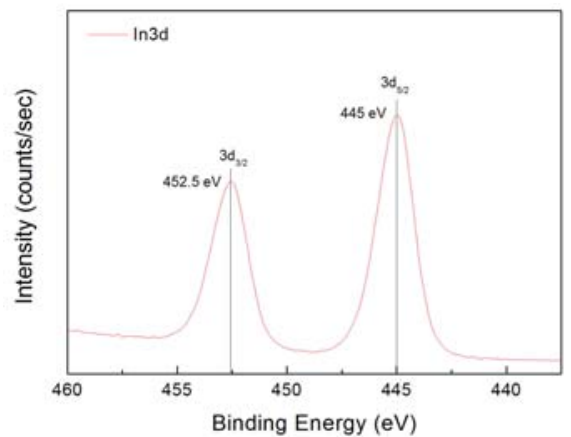

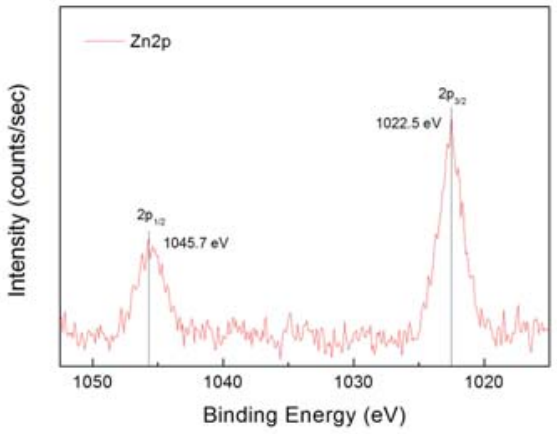
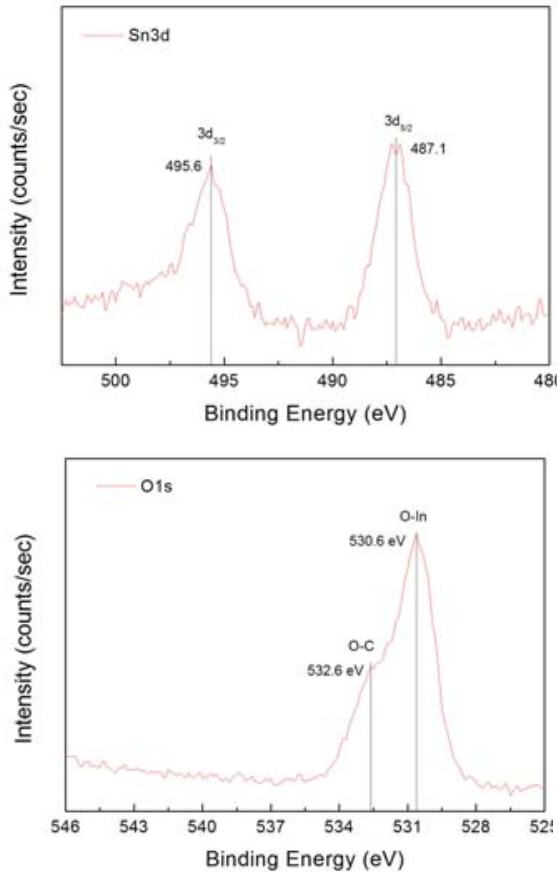

(b)

그림 7. RF 파워 $50 \mathrm{~W}$ 에서 증착한 ITZO 박막의 (a) XPS 와이드 스캔, (b) O 1s, In 3d, Sn 3d, Zn 2p 의 핵심 준위 스펙트럼

Fig. 7 (a) XPS wide scan, (b) core level spectra of $O$ 1s, In 3d, Sn 3d, Zn 2p for the ITZO thin film deposited at $50 \mathrm{~W}$

\section{$\mathrm{IV}$. 결 론}

본 연구에서는 고주파 마그네트론 스퍼터링 법으로 상온에서 RF 파워를 30 에서 $60 \mathrm{~W}$ 로 변화시켜가며 유리기판 위에 ITZO $\left(\mathrm{In}_{2} \mathrm{O}_{3}: \mathrm{SnO}_{2}: \mathrm{ZnO}=90 \mathrm{wt} . \%\right.$ : 
5wt.\% : 5wt.\%) 박막을 제작하여 전기적, 광학적, 구조 적 특성을 조사하였다. $\mathrm{RF}$ 파워 $50 \mathrm{~W}$ 에서 증착한 ITZO 박막이 $10.52 \times 10^{-3} \Omega^{-1}$ 의 가장 큰 재료평가지수 를 나타내었으며, 이때 $3.08 \times 10^{-4} \Omega-\mathrm{cm}$ 의 비저항과 $11.41 \Omega / s q$. 의 면저항으로 가장 우수한 전기적 특성을 나타내었다. 광학적 특성을 측정한 결과, 가시광 영역 (400 800 nm) 에서의 평균 투과도는 모든 ITZO 박막 에서 $80 \%$ 이상으로 나타났다. XRD 측정을 통해 $\mathrm{RF}$ 파워에 상관없이 모든 ITZO 박막이 비정질 구조를 가 지고 있음을 확인할 수 있었다. ITZO 박막의 표면을 $\mathrm{FESEM}$ 과 $\mathrm{AFM}$ 으로 관찰한 결과, 모든 ITZO 박막이 핀홀이나 크랙 같은 결함이 없는 매우 부드러운 표면을 가지며, RF 파워 $50 \mathrm{~W}$ 에서 증착한 박막이 $0.254 \mathrm{~nm}$ 의 가장 작은 표면 거칠기를 나타내었다.

본 연구를 통해 저온에서 증착한 비정질 ITZO 박막 이 우수한 전기적 및 광학적 특성을 나타내어 유기발광 다이오드와 같은 차세대 디스플레이에서 ITO 박막을 대체할 매우 유망한 재료라는 것을 알 수 있었다. 향후 플라스틱 기판을 이용한 ITZO 박막에 대한 연구를 체 계적으로 진행한다면, 플렉시블 디스플레이나 유기 태 양전지 등 광범위한 분야에서 매우 유용하게 사용될 수 있으리라 사료된다.

\section{감사의 글}

이 논문은 2012년도 전남대학교 학술연구비 지 원에 의하여 연구되었음.

\section{REFERENCES}

[1] T. Tsujimura, OLED Displays Fundamentals and Applications, New Jersey, Wiley, 2012.

[ 2 ] G. P. Crawford, Flexible Flat Panel Displays, New York, Wiley, 2005.

[ 3 ] H. K. Kim and K. S. Lee, "Effect of Introducting $\mathrm{H}_{2} \mathrm{O}$ Vapor on Properties of RF Sputter-Grown ITO Anode Layer for OLEDs," Electrochem. Solid-State Lett., vol. 11, pp. J57-J59, 2008.

[ 4 ] J. H. Bae, J. M. Moon, J. W. Kang, H. D. Park, J. J. Kim,
W. J. Cho, and H. K. Kim, "Transparent, Low Resistance, and Flexible Amorphous ZnO-Doped In2O3 Anode Grown on a PES Substrate," J. Electrochem. Soc., vol. 154, pp. J81-J85, 2007.

[ 5 ] D. H. Kim, W. J. Kim, S. J. Park, H. W. Choi, and K. H. Kim, "Electrical and Optical Properties of In-Zn-Sn-O Thin Film Deposited on Polymer Substrates Through Facing Targets Co-Sputtering System," Surf. Coat. Techno., vol. 205, pp. S324-S327, 2010.

[6] J. W. Kang, W. I. Jeong, J. J. Kim, H. K. Kim, D. G. Kim, and G. H. Lee, "High-Performance Flexible Organic LightEmitting Diodes Using Amorphous Indium Zinc Oxide Anode," Electrochem. Solid-State Lett., vol. 10, pp. J75-J78, 2007.

[ 7 ] J. H. Bae, J. M. Moon, S. W. Jeong, J. J. Kim, J. W. Kang, D. G. Kim, J. K. Kim, J. W. Park, and H. K. Kim, "Transparent Conducting Indium Zinc Tin Oxide Anode for Highly Efficient Phosphorescent Organic Light Emitting Diodes," J. Electrochem. Soc., vol. 155, pp. J1-J6, 2008.

[ 8 ] T. J. Marks, J. G. C. Veinot, J. Cui, H. Yan, A. Wang, N. L. Edleman, J. Ni, Q. Huang, P. Lee, and N. R. Armstrong, "Progress in High Work Function TCO OLED Anode Alternatives and OLED Nanopixelation," Synth. Met., vol. 127, pp. 29-35, 2002.

[9] H. M. Ali, "Characterization of a New Transparent Conducting Material of ZnO Doped ITO Thin Films," Phys. Stat. Sol. A., vol. 202, pp. 2742-2752, 2005.

[10] H. C. Pan, M. H. Shuao, C. Y. Su, and C. N. Hsiao, "Influence of Sputtering Parameter on the Optical and Electrical Properties of Zinc-doped Indium Oxide Thin Films," J. Vac. Sci. Technol. A, vol. 23, pp. 1187-1191, 2005.

[11] G. Haacke, "New Figure of merit for Transparent Conductors,", J. Appl. Phys., vol. 32, pp. 4086-4089, 1976.

[12] D. J. Son, Y. D. Ko, D. G. Jung, J. H. Boo, S. H. Choa, and Y. S. Kim, "Thermal Effect on Characteristics of IZTO Thin Films Deposited by Pulsed DC Magnetron Sputtering," Bull. Korean Chem. Soc., vol. 32, pp. 847-851, 2011.

[13] L. S. Hung and C. H. Chen, "Recent Progress of Molecular Organic Electro-luminescent Materials and Devices," Mater. Sci. Eng. R., vol. 39, pp. 143-222, 2002.

[14] K. H. Choi, J. A. Jeong, and H. K. Kim, "Dependence of Electrical, Optical, and Structural Properties on the Thickness of ITZO Thin Films Grown by Linear Facing Target Sputtering for Organic Solar Cells," Sol. Energy Mater. Sol. Cells, vol. 94, pp. 1822-1830, 2010. 
[15] J. M. Phillips, R. J. Cava, G. A. Thomas, S. A. Carter, J. Kwo, T. Siegrist, J. J. Krajewski, J. H. Marshall, W. F. Peck, Jr., and D. H. Rapkine, "Zinc-Indium-Oxide : A High Conductivity Transparent Conducting Oxide," Appl. Phys. Lett., vol. 67, pp. 2246, 1995.

[16] T. Ishida, H. Kobayashi, and Y. Nakato, "Structures and Prpperties of Electron-Beam-Evaporated Indium Tin Oxide
Films as Studied by X-ray Photoelectron Spectroscopy and Work-Function Measurements," J. Appl. Phys., vol. 73, pp. 4344-4350, 1993.

[17] K. H. Lee, H. W. Jang, K. B. Kim, Y. H. Tak, and J. L. Lee, "Mechanism for the Increase of Indium-Tin-Oxide Work Function by $\mathrm{O}_{2}$ Inductively Coupled Plasma Treatment," J. Appl. Phys., vol. 95, pp. 586-590, 2004.

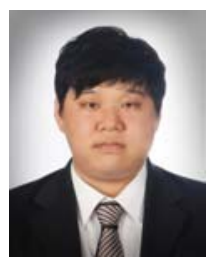

\section{서진우(Jin-Woo Seo)}

2013년 8월 전남대학교 전기 및 반도체공학과 졸업(공학석사)

※관심분야 : 반도체 재료 및 공정

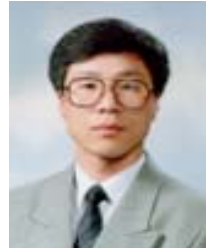

정양희(Yang-Hee Joung)

1985년 8월 인하대 응용물리학과 졸업(공학석사)

1993년 8월 인하대 전자재료공학과 졸업(공학박사)

1988 1995년 LG반도체 선임연구원

1995 현재 전남대학교 전기 및 반도체공학과 교수

※관심분야 : VLSI 공정 및 반도체 물성

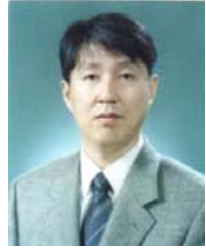

\section{강성준(Jun-Seong Kang)}

1994년 8월 인하대 전자재료공학과 졸업(공학석사) 1999년 2월 인하대 전자재료공학과 졸업(공학박사)

2000년 현재 전남대학교 전기 및 반도체공학과 교수

※관심분야 : II-VI 화합물 반도체, 기능성 박막, 반도체 공정 및 재료 